\title{
Conservación de las estructuras de hormigón y metálicas, en una fábrica de abonos
}

T. W. SWAMINATHAN

Indian Concete Jour. V. 5, N.o 8, pág. 234, agosto 1977

Describe el autor los problemas que se presentan en la conservación de las estructuras de hormigón y metálicas de la fábrica de abonos de Neyveli, y las medidas de protección que le han dado mejor resultado.

\section{CORROSION DEBIDA A LA UREA}

La urea es una base débil; el pH de su disoluciór acuosa al $10 \%$, es de 7,2 a 7,9. Es muy soluble en el agua y se hidroliza originando productos muy agresivos para el hormigón y el hierro.

No se conoce con exactitud la naturaleza del ataque químico de la urea al hormigón; se ha observado que las disoluciones de urea penetran por los poros del hormigón y cristaliza la urea con gran aumento de volumen causando la destrucción del mortero cementante, dejando al descubierto las armaduras que se corroen. La penetración es muy variable según la clase de hormigón; en las losas del pavimento alcanzó hasta $200 \mathrm{~mm}$.

\section{Tratamiento}

Cuando el ataque es severo, se quita mecánicamente el hormigón dañado y la superficie que se encuentre sana se lava durante varios días con un chorro de agua con el fin de extraer, en lo posible, la urea que aún subsista. A continuación se revoca la estructura con mortero de cemento $1: 3 \frac{1}{2}$ y como armadura una malla metálica. La superficie así cubierta se trata con dos capas de fluosilicato: después de curado y seco, se pinta con dos manos de una pintura epoxi. Este tratamiento ha dado buen resultado aunque la urea, que en algún lugar hubiese quedado, al cabo de unos años produce fisuras, pero en general la protección subsiste.

\section{CORROSION DE LAS ESTRUCTURAS METALICAS}

Normalmente los álcalis fuertes atacan las estructuras metálicas debido a que la urea tiene, en disolución, un $\mathrm{pH}$ de 9,5 y es higroscópica, actúa como un fuerte agresivo. En la fábrica las columnas y vigas formaban la estructura metálica, mientras el techo lo componían chapas de asbesto-cemento. La corrosión del hierro llegó a reducir a la mitad ei 
espesor de los perfiles en cinco años. No fue posible lavar ni secar las superficies, ni siquiera con sopletes, pero al quitar las chapas del techo se obtuvo el secado entre las 11 y 15 horas.

\section{Tratamiento}

Las superficies que debían protegerse se lavaron y cepillaron, dejándolas secar 15 horas; se aplicó una pintura epoxi. Los espacios cerrados se recubrieron con asfalto armándolo con mallas de hierro y el interior de las columnas se rellenó con mortero de cemento.

\section{CORROSION DEBIDA A LA LEJIA}

$\mathrm{El} \mathrm{pH}$ de la lejía es de 9,3 y la composición de la usada en la fábrica es: $\mathrm{K}_{2} \mathrm{O}=100 \mathrm{~g} / \mathrm{l}$, $\mathrm{As}_{2} \mathrm{O}_{3}=180 \mathrm{mg} / \mathrm{l}, \mathrm{As}_{2} \mathrm{O}_{5}=20 \mathrm{mg} / l$ se usa para descarbonatar los gases.

El hormigón bien compactado no es atacado por esta lejía, pero generalmente es lo suficientemente poroso para que se produzca una penetración que altera la unión con las armaduras; los arsenitos y arseniatos reaccionan con los constituyentes del cemento, y el mortero resulta severamente atacado.

\section{Tratamiento}

Revestir las superficies expuestas a la lejía con hormigón muy denso, $1: 1 \frac{1}{2}: 3 \mathrm{y}$, después, aplicar un tratamiento con fluosilicato. Son eficaces las pinturas epoxi, pinturas a base de caucho y mástique asfáltico, siempre que la temperatura no exceda de $40^{\circ} \mathrm{C}$.

\section{CORROSION DEBIDA AL ACEITE}

Los aceites minerales no atacan al hormigón, pero si contienen aceites vegetales, éstos saponifican al hidróxido cálcico y destruyen el mortero. En algunos lugares de la fábrica el aceite penetró hasta $60 \mathrm{~mm}$.

\section{Tratamiento}

Después de raspar y lavar las superficies, se aplicó una disolución de fluosilicato que resultó efectiva; también dieron buenos resultados las pinturas de epoxi, clorocaucho y el revestimiento con losetas vidriadas. 